\title{
6) $\mathrm{H}$ 占 $M \in \amalg \kappa \circ \breve{И ̆}$
}

151. Reckmann. - Zur Aetiologie der Inversio uteri post partum. (Zeitschr. f. Geb. und Gyn., Bd. XXXI, Hft. 2). $\mathbf{K}_{\mathbf{b}}$ этіологіи посльродоваго выворота матки.

На основаніи одного собственнаго наблгденія, въ которомъ вывороть образовался безъ всякаго вньшняго насилія, а также

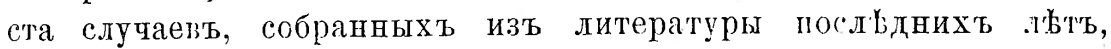
авторт приходить къ тому заключенію, что самостолтельный выворотьь вовсе не такъ рыдокь, как'ь это привыкли думать, а что онъ наобороть наблюдается чаще, чьым насильственный.

С. Ю. Хазанг.

152. A. Goenner.-Zur Hinterscheitelbeineinstellung. (Zeitschr. f. Geb. und Gyn., Bd. XXXI, Hft. 2). $\mathbf{K}_{\mathbf{b}}$ учөнію о задней позиціи төмянною костью.

Неправильное вставленіе головги, при которомь задняя, обращенная къ мысу темянная кость находится падъ тазовымь вхо-

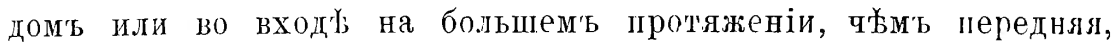
наблгдалось в'ь Базельской клиник'ь 8 разъ на 2400 роцовт и преимущественио ири узюмь тазъ. ІІри этомь липь трое дытей и семь матерей остались въ живых'ь двое д'ътей умерли во время акта родовт, а трое были перфорированы; одна изъ матерей умерла всльдствіе разрыва матки. Только разь роды окончились самопроизвольно, въ двух'ь случаях'ь быль сдылань повороть на ножки, в’ь одномт, случат-лапоротомія, въ трехт случаяхь была произведена перфорація, а в'ь одном'ь случа'ь головка была иввлечена щицами при одновременномь исправленіи неправильной позиціи вну'ренними манипуляціями уже по наложеніи щипцовъ.

С. Ю. Хазанг.

153. Schaller.-Zur Gasuistik des Vagitus uterinus. (Zeitschr f. Geb. und Gyn., Bd. XXXI, Hft. 2). Къ казуистикв утробнато крика плода.

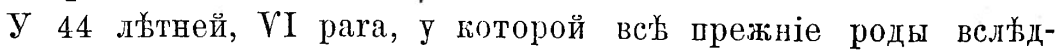
ствіе узкости таза оканчивались помощью искусства, быль сды ланъ, 13 часовъ посл'ь отхода обильныхъ водъ, поворот'ь на ножки при ненолнов раскрытіи зъва и слабыхь болях. Вь тоть самый моменть, когда кольно погазалось у наружныхъ половыхь qастей, 
Sch. услышаль своеобразные звуки, исходяпіе изъ матки. Выпустивь изь рукъ ножку, онь сталь прислушиваться приложивь ухо к'ь матк' з; звуков'ь онь однако больше не разслышал'ь, но зато одновременно съ правильными сердечными тонами явственно ощущаль дыхательныя движенія плода. Koгда Sch. опять потянуль за ножку, 'то он'ь, равно какь и веј присутствовавшіе при родах'ь, опять услышали явственный крикъ ребенка, повторивпійся сь промежутками нъсколько раз'ь въ продолженіи 20 секундь, при чемъ ири аускультаціи живота можно было констатировать реснира'торный шумт. Sch. вновь вышустиль изь рукь ножку и опять потянуль за нее, но крикь уже болье не повторился. Такь какь сердщебіеніе плода стало замедлятєся, то приступили кь извле-

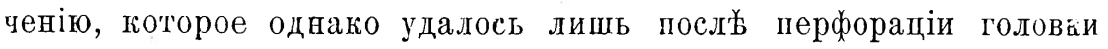
тым временемь умершаго плода. Шри секціи посльдняго оказалось, что правое и сџеднее легкое, равно какъ желудок' содержали въ себ' воздух'ь и при погруженіи въ воду плавали. Приведенное наблгденіе, въ которомь крик'ь и дыханіе ребенка имґло мъсто при наличности плящентарнаго кровообращенія, заслуживаеть, уо мнънію автора, еще оеобеннаго вниманія, поскольку оно можеть служить доказательствомь въ пользу теоріи Freyer'a o роли раздраженія кожи при наступленіи перваго дыханія.

\section{С. ҒО. Хазано.}

\section{Emanuel Wittkowsky und Veit.-Ueber Endometritis} in der Gravidität. (Zeitschr. f. Geb. und Gyn., Bd. XXXII, Hft. 1). Endometritis во время беременности.

E. два раза, у одной и той же молодой многорожавшей, наблюдаль выкидышь. Въ обоихьь случаяхь decidua оказалась сильно утолщенною и пораженною, въ особенности на поверхности, мелкокльтчатымъ инфильтратомь; но посль обработки ихъ шо методу Gram-Weigert'a, между объими deciduae оказалась существенная разница. Въ то время какъ при выкидышь, произшедшемт $2^{1 / 2}$ roда тому назадь, въ decidua обнаруженн были кокки, при посльднемь выкидып年 бы.и найдыш и́ациллы, которыл $W$. удалось даже демонстрировать зъ qистой разводкъ.

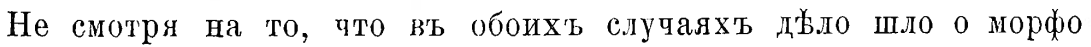
логически соверпенно различныхъ микробахэ, $E$. склонень видъгь въ нихъ настоящихъ виновниковь этого характернаго воспалительнаго продесса. Veit, вь клиникь котораго были произведены изслььдованія $E$. $W$., хотя и признаеть, что этими изсльдованіями вопрось объ этіологіи endometritis gravidarum 